University of Nebraska - Lincoln

DigitalCommons@University of Nebraska - Lincoln

June 2002

\title{
Policymaking Network of the Iron-Triangle Subgovernment for Licensing Hazardous Waste Facilities
}

\author{
F. Gregory Hayden \\ University of Nebraska - Lincoln, ghayden1@unl.edu
}

Follow this and additional works at: https://digitalcommons.unl.edu/cbafacpub

Part of the Business Commons

Hayden, F. Gregory, "Policymaking Network of the Iron-Triangle Subgovernment for Licensing Hazardous Waste Facilities" (2002). College of Business Faculty Publications. 8.

https://digitalcommons.unl.edu/cbafacpub/8

This Article is brought to you for free and open access by the Business, College of at DigitalCommons@University of Nebraska - Lincoln. It has been accepted for inclusion in College of Business Faculty Publications by an authorized administrator of DigitalCommons@University of Nebraska - Lincoln. 


\section{Policymaking Network of the Iron-Triangle Subgovernment for Licensing Hazardous Waste Facilities}

\section{F. Gregory Hayden}

The purposes here are to explain the linkage of (1) economic methodology, (2) corporate networks, and (3) federal court decisions in the licensing of hazardous waste facilities and to recognize the opportunity the combination of the three provides for institutional economists. ${ }^{1}$ The United States has the best and most comprehensive set of laws we might expect from a legislative process in order to prevent human disease, loss of property, and ecological system destruction from hazardous, toxic, and radioactive waste. Yet the licensing process and assessment that has grown out of that legislation has not produced the protection expected. The waste disposal problem continues to grow.

The National Environmental Policy Act (NEPA) of 1969 is another achievement of the "Greatest Generation." It was the world's first environmental policy of such proportion, and it became a model for environmental policies and legislation in nations around the globe for protecting the environment (see Colombo 1992). Consistent with institutionalism, NEPA has been called "an organic act for environmental protection" (Ringquist 1999, 88). The approximately 50,000 NEPA environmental assessments prepared annually are an indication that the influence NEPA is to have on comprehensive planning is intended to be pervasive.

The principal tools of NEPA for assessing impacts and planning actions are the environmental impact assessment (EIA) and the environmental impact statement (EIS). The purpose of the EIA is to ensure that appropriate attention is given to environmental issues. It is to provide adequate information on projects such as waste disposal projects that affect the environment. "All environmentally relevant impacts of such

The author is Professor of Economics, University of Nebraska-Lincoln. This paper was presented at the annual meeting of the Association for Evolutionary Economics, Atlanta, Georgia, USA, January 4-6, 2002. The author wishes to express his appreciation to Pam Royal for her assistance in the completion of this work, to Jan Hime for the graphics, and to legal experts too numerous to mention for legal research assistance. 
activities should be identified, analyzed and evaluated before consent is given" (Colombo 1992, 1). In addition to analytical information, the EIA includes scoping, consultation of other authorities, and public participation. An EIS is prepared to investigate environmental consequences of alternatives for pursuing a proposed project and must be used by decision makers in reaching a final decision. The EIS is to include the environmental impact of the proposed action, any adverse environmental effects which cannot be avoided, and any irreversible and irretrievable commitments of resources which might be involved in the proposed action (Eccleston 2001, 9).

\section{Economists Have Failed to Provide a NEPA Welfare Paradigm}

Although legislators have provided an appropriate legal apparatus for evaluation, waste production and disposal problems continue to grow. This is due in part to the failure of economics to provide a welfare paradigm that is relevant, reasonable, and applicable. NEPA expresses a holistic and organic concern about general welfare. Economists are expected to provide for welfare analysis and efficiency measures, but an acceptable paradigm does not exist. Neoclassical cost-benefit analysis has been rejected for NEPA assessments for all the reasons that institutionalists have rejected it. It is now "settled that NEPA does not require a cost-benefit analysis ..." (Anderson et al. 1999, 284).

The court seriously questioned the basis for neoclassical analysis where it ruled that "natural resources have value that is not readily measured by traditional means" (Ohio v. Interior 1989, 785). The traditional means of concern in neoclassical cost-benefit analysis is market price, about which the court stated, "it is unreasonable to view market price as the exclusive factor, or even the predominant one.... [N]atural resources have values that are not fully captured by the market system" (Ohio v. Interior 1989, 486). Thus, the court found that the Department of Interior "erred by establishing a strong presumption in favor of market price and appraisal methodologies" (Ohio v. Interior 1989, 786). Other schools of economics have failed to provide alternative methodologies. How is a reviewing agency to integrate and balance the volumes of analysis and information from experts in geology, economics, biology, hydrogeology, engineering, and physics? Economists have not provided acceptable standards, criteria, analytical methodologies, or procedures for completing such analysis. The theoretical divisions in economics make it impossible for decision makers and courts to select a set of theories and consequent criteria upon which to make decisions. Economists are to provide assistance in knowing goods and services from bads and disservices and to provide guidance about how to determine what is efficient. "Efficient" means producing a desired effect. Yet, agencies and courts have not found evaluation tools or standards in economics that are sufficient for real-world application. As the court stated in Ohio v. Interior, efficiency means "the result that achieves the greatest value to society. Whether a particular choice is efficient depends on how the various alternatives are valued" $(1989,473)$. Economists have pro- 
vided little viable assistance with regard to how to select alternatives according to societal beliefs and values. ${ }^{3}$

The failure of economists has been to the benefit of powerful corporations, who have dominated many licensing decisions through subgovernment networks and through their ability to hire expertise.

\section{The Iron-Triangle Subgovernment Model}

James Swaney has explained that the corporate elite controls hazardous technologies, that information about the technologies is often shielded from public scrutiny, and that, consequently, the elite possesses the power to impose risks on an uninformed, unsuspecting public (Swaney 1995, 578). The reason the public is so uninformed and unsuspecting is because of the power gained over the information and analysis process by what political scientists have termed "iron triangles," or "subgovernments." The subgovernment explanation to policymaking is based on the reality that small groups of actors dominate certain sectors of the political system. Subgovernmental groups that compose the three sides of the iron triangle consist of (1) government bureaucrats in executive positions, (2) a legislative committee or commission to which the legislative process delegated authority, and (3) an integrated corporate interest group. The participants organize into mutually reinforcing relationships between regulated interests and regulators. In the case of hazardous waste, the corporations dominate the decision process about the definition of the problem and are the entity that completes much of the analysis and data collection.

An example of an integrated corporate network, taken from the database of another article, is illustrated in figure 1 (Hayden, Wood, and Kaya 2002). The twelve corporations in figure 1 are the most dominant corporations among seventy-two corporations that make up the integrated network surrounding a subgovernment of a multi-state compact organized to site a radioactive waste disposal facility. The basic measurement unit is the "power bloc," which is a set of corporations integrated by interlocking boards of directors, as follows: Peter Kiewit \& Sons' $<=>$ Berkshire Hathaway $<=$ CalEnergy $<=>$ Illinois Power. This is an example of four global corporations with common energy interests who produce hazardous, toxic, and radioactive waste. The directed lines between the corporations represent the exchange of one or more directors between corporations. The combination of the four corporations is one power bloc.

Some examples of power bloc involvement among the twelve well-known global corporations in figure 1 are

- Berkshire Hathaway is a member of 421 different power blocs among the seventy-two corporations.

- Peter Kiewit \& Sons' is a member of 489 different power blocs.

- Entergy is a member of 319 . 
- CalEnergy participates in 570.

- Illinois Power is a member of 555 different overlapping power blocs.

As displayed in figure 1, among the twelve most dominant corporations, every corporation is involved in power blocs with every other corporation. Connecting lines in figure 1 represent, on the average, eighty-five different power blocs to which the two corporations share membership among the power blocs of the seventy-two corporations (Hayden, Wood, and Kaya 2002). The integrated policy coordination of such a dense network makes for excessive corporate power in any subgovernment arrangement. Thus, the corporations can dominate the EIS and EIA process to arrive at conclusions to approve their projects. If public groups disagree with an agency's approval, the decision must be appealed in the courts after the fact.

\section{Figure 1. Power Bloc Connections Among the Twelve Most Dominant Subgovernment Corporations}

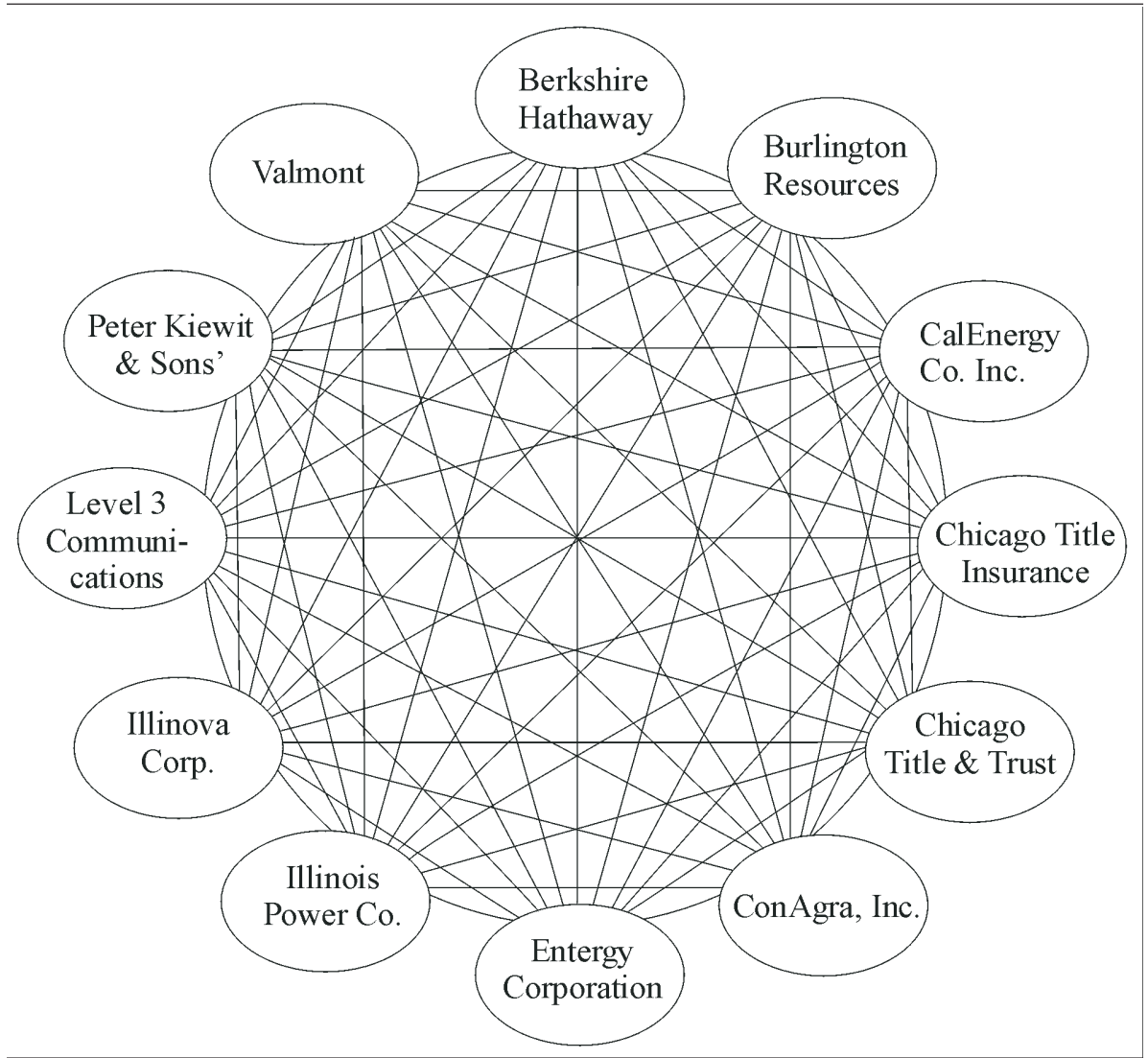

Note: A "power bloc" is a set of four corporations that are linearly connected by interlocking directorships. Average number of different power blocs represented by each line that connects two corporations is eighty-five. 


\section{Federal Court Review of Agency Decisions}

Although federal courts have ruled that they can review an agency's compliance with the applicable laws and regulations, this does not necessarily mean that the courts can reverse the substantive decision made by the agency. Federal courts have focused on the extent to which they should defer to the discretionary decision making of the agency.

In Citizens to Preserve Overton Park, Inc. v. Volpe (1971, 837), the US Supreme Court applied the "arbitrary and capricious" standard to an agency decision made under NEPA on whether or not to prepare an EIS. The Supreme Court has indicated that this standard may also apply to other agency actions taken under NEPA. The Court then held that the "generally applicable" standards of the Federal Administrative Procedure Act require the "reviewing court to engage in a substantial inquiry" (Marsh v. Oregon 1989, 360). This statement led some courts to adopt what has come to be known as the "hard look" doctrine in reviewing agency decisions.

Judge Leventhal of the District of Columbia Court of Appeals was the first to espouse the hard look doctrine. He explained: "Its supervisory function calls on the court to intervene not merely in the case of procedural inadequacies, or bypassing the mandate in the legislative charter, but more broadly if the court becomes aware, especially from a combination of danger signals, that the agency has not really taken a hard look at the salient problems, and has not genuinely engaged in reasoned decision-making" (Greater Boston v. Federal Communications Commission 1972, 950). In other words, the court must take a hard look to ensure that the agency has taken a hard look: "[A]ssumptions must be spelled out, inconsistencies explained, methodologies disclosed, contradictory evidence rebutted, record references solidly grounded, guesswork eliminated and conclusions supported in a 'manner capable of judicial understanding'" (E. I. duPont v. Train 1977, 1038).

The hard look test has also been adopted by the Fifth Circuit of the United States Court of Appeals in the context of reviewing the adequacy of an EIS (Isle of Hope, etc. v. U.S. Army Corps 1981, 220). The US Supreme Court has reviewed the doctrine on several occasions since its adoption, and although it has given conflicting signals as to its vitality, the doctrine continues to be valid (Chevron v. Natural Resources 1984, 837). Economists have not assisted the courts by providing analytical tools for a hard look.

Even in the face of the hard look doctrine, courts consider their role in reviewing agency decisions to be limited. Under the arbitrary and capricious standard, the court's review is narrow, and the agency needs only to articulate a rational connection between the facts found and the conclusions made (ONRC v. Lowe 1997, 521). And, more importantly, the US Supreme Court has concluded that a court cannot overturn an agency's substantive decision on the merits if it has not complied with NEPA. "The only role for a court is to insure that the agency has taken a 'hard look' at environmental consequences; it cannot interject itself within the area of discretion of the executive as to the choice of the action to be taken" (Kleppe v. Sierra Club 1972, 411n.2). In a later case, the Court stated in dicta: "NEPA does set forth significant substantive goals for the Nation, 
but its mandate to the agencies is essentially procedural . . . . It is to insure a fully informed and well-considered decision, not necessarily a decision ... this Court would have reached had they been members of the decisionmaking unit of the agency. Administrative decisions should be set aside in this context ... only for substantial procedural or substantive reasons as mandated by statute, . . . not simply because the court is unhappy with the result reached" (Vermont Yankee v. Natural Resources 1978, 558). In Strycker's Bay v. Karlen, the district court ruled that HUD was not required to either prepare an impact statement or consider alternatives. However, the Supreme Court noted that NEPA duties were "essentially procedural" (1980, 227-228), citing Vermont Yankee, and did not allow the court to substitute its decision for the agency's. A court will usually refuse to substitute its judgment for that of the reviewing agency regarding how the agency should have weighed the evidence in determining whether to issue permits (Isle of Hope, etc. v. U.S. Army Corps 1981, 220). The issuance of a permit will not be disturbed as long as the decision of the reviewing agency was not "arbitrary and capricious" (Sierra Club v. Morton 1975, 818). If the evaluation conducted by the agency "makes sense," is a "reasoned decision," and is founded on a "reasoned evaluation of the relevant factors," the agency's decision will pass muster under the arbitrary and capricious test (Dubois v. U.S. Dept. of Agriculture 1997, 1235). "The court is not empowered to substitute its judgment for that of the agency" (Citizens v. Volpe 1971, 467). With these standards of review and the knowledge that a decision will be reversed only for a substantial procedural error or a failure to comply with a statutory mandate, a review of the requirements of law indicates that a court reversal is highly unlikely.

A review of federal rules and regulations regarding the EIA provides a laundry list of topics that is required to be included in the EIA. The topics that are required to be included in the EIA appear to be straightforward, and, according to statutory and regulatory authority, the EIA is required only to "address," "assess," and/or "consider" each of these topics. Currently, even if the assessment by the agency is minimal, a court will not substitute its judgment for that of the agency.

One of the most common challenges made to an agency's decision is to attack the sufficiency of the EIS prepared by the agency. Just as courts have adopted a hard look test in reviewing an agency decision, a minority of courts has also adopted a similar test when reviewing the adequacy of an EIS. The function of the federal court is only to determine whether the plaintiff has established "by a preponderance of the evidence, rather than by a prima facie showing of deficiencies that the EIS ... was inadequate" (Isle of Hope, etc. v. U.S. Army Corps 1981, 220). While aware that NEPA requires the EIS to be a "detailed statement," the court does not place "extreme or unrealistic burdens on the compiling agency" (220). With these admitted limitations, the hard look test appears to be hard in name only and not in its application.

A majority of courts have adopted a "rule of reason" standard that modifies or softens the hard look test with regard to the EIS. The rule of reason is used to determine the adequacy of the impact statement. 
Regardless of the judicial review standard employed when reviewing the adequacy of an EIS, the courts clearly consider their role in reviewing the EIS as strictly limited. As long as the evaluation conducted by the agency "makes sense," is a "reasoned decision," and is founded on a "reasoned evaluation of the relevant factors," the agency's decision will pass muster under the arbitrary and capricious test (Dubois v. U.S. Department of Agriculture 1997, 1285). "The court is not empowered to substitute its judgment for that of the agency" (Citizens v. Volpe 1971, 402).

\section{Concluding Remarks}

Court decisions regarding NEPA, as implemented, configure as follows: First, the courts are reluctant to overrule the judgment of the decision-making agency, whether it has denied or granted an application for a license or included or not included certain information. The courts have not been provided acceptable methodology, or analytical technique for valuation or efficiency determination, upon which to base rejection. Second, courts seem to be without a legitimate standard about which entity has the authority to complete and assess environmental impact studies, in that courts have allowed corporations that are the facility developers to review and assess the adequacy of their own environmental analysis. Third, courts have stated that numerous alternative analyses are acceptable-alternatives such as cost-benefit analysis, risk assessment, cost-effectiveness, network analyses, or simple lists of impacts. Fourth, it appears that the courts will allow almost any kind of analysis that was worked upon in a diligent manner.

The acceptance of almost any kind of analysis that has the appearance of being worked on in a diligent manner is a dream come true for large corporations. They have plenty of funds to hire experts and consulting firms to give the appearance of diligence on their own license applications and when assisting agencies in the preparation of the EIA and EIS or when agencies allow the corporations to assess their own license application. If a license decision is challenged in court by public groups, the large integrated corporations have deep pockets to demonstrate in court that the work was done in a diligent manner.

The current situation allows an opportunity for institutional economists to provide methodology, modeling, and database development consistent with the holistic and organic intent of NEPA. Such assistance would be welcomed by many government agencies and public advocacy groups who are concerned about protecting the environment. Institutional economics is consistent with the intent of NEPA. Equally important, such a concerted effort by institutionalists would help challenge and constrain the undue influence of corporations in government agencies. 


\section{Notes}

1. As used in this article, "institutional" refers to work in the tradition of the original institutional economics (OIE), not the new institutional economics (NIE).

2. The "Greatest Generation" (from the book of the same name) in the United States is the generation that grew up during the Great Depression of the 1930s, fought in World War II in the 1940s, and (those who returned from the war) came home to build a prosperous economy and establish legislation, government programs, nongovernmental agencies, and advocacy organizations in order to provide for a good life for US citizens.

3. Institutional economists-from John R. Commons to Harry R. Trebing-have provided analytical frameworks for analysis in areas other than environmental assessment.

\section{References}

Anderson, Frederick R., Robert L. Glicksman, Daniel R. Mandelkev, and A. Dan Torlock. Environmental Protection: Law and Policy. New York: Aspen Law and Business, 1999; updated online. Available from Internet: University of Kansas, <http://lawstudy.law.ukans.edu/glicks/envprot/7-updt99.htm>, accessed August $1,2001$.

Chevron, U.S.A., Inc. v. Natural Resources Defense Council, Inc., 467 U.S. 837 (1984).

Citizens to Preserve Overton Park, Inc. v. Volpe, 401 U.S. 402 (1971).

Colombo, A. G., ed. Environmental Impact Assessment. Boston: Kluwer Academic Publishers, 1992.

Dubois v. U.S. Department of Agriculture, 102 F.3d 1273 (1st Cir. 1996), cert. denied, 117 S.Ct. 250 (1997).

Eccleston, Charles H. Effective Environmental Assessments: How to Manage and Prepare NEPA EAs. New York: Lewis Publishers, 2001.

E. I. duPont de Nemours $\mathcal{E}$ Co. v. Train, 541 F.2d 1018 (4th Cir. 1976), affirmed in part and reversed in part, 430 U.S. 112 (1977).

Greater Boston Television Corp. v. Federal Communications Commission, 444 F.2d 84 (D.C. Cir. 1970), cert. denied, 401 U.S. 950 (1972).

Hayden, F. Gregory, Kellee R. Wood, and Asuman Kaya. "The Use of Power Blocs of Integrated Corporate Directorships to Articulate a Power Structure: Case Study and Research Recommendations." Journal of Economic Issues (forthcoming).

Isle of Hope, etc. v. U.S. Army Corps of Engineers, 646 F.2d 215 (5th Cir. 1981).

Kleppe v. Sierra Club, 427 U.S. 390 (1976).

Marsh v. Oregon Natural Resources Council, 4990 U.S. 360 (1989).

Ohio v. U.S. Department of Interior, 880 F.2d 422 (1989).

ONRC v. Lowe, 109 F.3d 521 (9th Cir. 1997).

Ringquist, Evan J., and David H. Clark. “Local Risks, States' Rights, and Federal Mandates: Remedying Environmental Inequities in the U.S. Federal System." The Journal of Federalism 29 (spring 1999): 73-93.

Sierra Club v. Morton, 510 F.2d 813 (5th Cir. 1975).

Strycker's Bay Neighborhood Council v. Karlen, 444 U.S. 223 (1980).

Swaney, James A. "Social Economics and Risk Analysis." Review of Social Economy 53 (winter 1995): 575-594.

Vermont Yankee Nuclear Power Corp. v. Natural Resources Defense Council, Inc., 435 U.S. 519 (1978). 